\title{
Epidemiological features of meningiomas: a single Brazilian center's experience with 993 cases
}

\author{
Características epidemiológicas de meningiomas: experiência de um centro único \\ brasileiro com 993 casos
}

\author{
Benedicto Oscar COLLI', Hélio Rubens MACHADO', Carlos Gilberto CARLOTTI JR', João Alberto ASSIRATI \\ JR', Ricardo Santos DE OLIVEIRA', Guilherme Gozzoli Podolsky GONDIM1, Antonio Carlos DOS SANTOS², \\ Luciano NEDER ${ }^{3}$
}

\begin{abstract}
Background: Meningiomas are the most frequent primary central nervous system (CNS) tumors. Their geographical and ethnic characteristics need to be known, in order to enable rational treatment. Objective: To investigate clinical and epidemiological aspects in a series of patients with meningiomas. Methods: Retrospective analysis on the demographic profile, location and histopathology of 993 patients with meningiomas (768 operated and 225 not operated). Results: Meningiomas represented $43.8 \%$ of the primary CNS tumors; $6.8 \%$ were multiple tumors ( $14.7 \%$ with neurofibromatosis 2 ) and $0.6 \%$ were radiation-induced tumors. The mean ages were 53.0 and 63.9 years for operated and non-operated patients and the female/male ratios were 3.2:1 and 6.3:1. Diagnosis was made later among females. The peak incidences were in the $6^{\text {th }}$ and $7^{\text {th }}$ decades respectively for operated and non-operated patients. The incidence was low at early ages and higher among patients aged $70+$ years. The meningiomas were intracranial in $96.5 \%$ and most were WHO grade I (88.9\%) and transitional. In the spinal canal (3.5\%), they occurred mainly in the dorsal region (all grade I; mostly transitional). The racial distribution was $1.0 \%$ in Asian-Brazilians, $87 \%$ in Caucasians and $12 \%$ in African-Brazilians. $83.4 \%$ and $51.6 \%$ of the patients were estimated to be recurrence-free at 10 and 20 years, and the mortality rate was $3 \%$. Conclusions: Most of the demographic data were similar to what has been observed in other western centers. Differences were higher incidence of meningiomas, female and older predominance in nonoperated patients, predominance in Caucasian, and higher association with neurofibromatosis 2.
\end{abstract}

Keywords: Meningioma; Demographic Data; Pathology; General Surgery; Risk Factors; Neoplasm Recurrence, Local.

\section{RESUMO}

Antecedentes: Meningiomas são os tumores mais frequentes do sistema nervoso central (SNC). Suas características étnicas e geográficas precisam ser conhecidas para o seu tratamento racional. Objetivo: Investigar aspectos clínicos e epidemiológicos de uma série de pacientes com meningiomas. Métodos: Análise retrospectiva demográfica de 993 pacientes com meningiomas (768 operados e 225 tratados conservadoramente). Resultados: Meningiomas constituíram 43.8\% dos tumores primários do SNC. 0.8\% deles eram múltiplos (14,7\% com neurofibromatose 2) e 0,6\% eram radioinduzidos. A idade média e o índice mulheres/homens foram respectivamente 53,0 e 63,9 anos e 3.2:1 e 6.3:1 para pacientes operados e não operados. O diagnóstico foi mais tardio em mulheres. Ocorreram picos de incidências na $6^{a}$ e na $7^{a}$ décadas respectivamente para pacientes operados e não operados. A incidência foi menor na infância e maior após 70 anos. Meningiomas predominaram no crânio (96.5\%), a maioria grau I da OMS, subtipo transicional. Do total, 3.5\% ocorreram no canal raquídeo, principalmente na região torácica, todos grau I, a maioria transicional. Em relação à distribuição racial, $1.0 \%$ dos meningiomas ocorreu em amarelos, $87 \%$ em brancos e $12 \%$ em negros. As taxas de sobrevida sem recorrência foram $83.4 \%$ e $51.6 \%$ em 10 e 20 anos e a mortalidade operatória foi 3\%. Conclusões: A maioria dos dados demográficos observados foi similar aos de outros centros ocidentais. As diferenças observadas foram maior incidência, predominância em mulheres e idosos nos pacientes não operados e em caucasianos, e maior associação com neurofibromatose 2 .

Palavras-chave: Meningioma; Dados Demográficos; Patologia; Cirurgia Geral; Fatores de Risco; Recidiva Local de Neoplasia.

\footnotetext{
1 Universidade de São Paulo, Faculdade de Medicina de Ribeirão Preto, Departamento de Cirurgia, Divisão de Neurocirurgia, Ribeirão Preto SP, Brazil.

${ }^{2}$ Universidade de São Paulo, Faculdade de Medicina de Ribeirão Preto, Departamento de Imagem Médica, Hematologia e Oncologia Clínica, Ribeirão Preto SP, Brazil.

${ }^{3}$ Universidade de São Paulo, Faculdade de Medicina de Ribeirão Preto, Departamento de Patologia, Ribeirão Preto SP, Brazil.

BOC (1) https://orcid.org/0000-0002-0222-6770; HRM https://orcid.org/0000-0002-1069-7804; CGC JR (D) https://orcid.org/0000-0002-7055-0564; JAA JR (D) https://orcid.org/0000-0001-6772-2129; RSDO (D) https://orcid.org/0000-0003-0390-5553; GGPG (D) https://orcid.org/0000-0002-9608-2607; ACDS (1D https://orcid.org/0000-0002-5502-4734;LN (D) https://orcid.org/0000-0003-3790-3476

Correspondence: Benedicto Oscar Colli; Email: bocolli.@fmrp.usp.br.

Conflict of interest: There is no conflict of interest to declare.
}

Authors' contributions: BOC: conceptualization, investigation, data curation, writing; HRM, CGCJ, JAAJ: conceptualization, investigation (supporting); RSO, GGPG: data curation, investigation, writing original raft, writing-review (supporting); ACS, LN: investigation, validation (supporting).

Received on September 21, 2020; Received in its final form on October 26, 2020; Accepted on November 04, 2020. 


\section{INTRODUCTION}

Meningiomas arise from meningothelial cells of the arachnoid layer, which covers the brain. They occur primarily at the base of the skull in the parasellar regions and over the cerebral convexity ${ }^{1}$. Meningiomas have become the most common type of all primary central nervous system (CNS) tumors over the last decade ${ }^{1,2,3}$. They account for $35.8 \%$ of all CNS tumors and for more than $53 \%$ of all benign CNS tumors diagnosed, with a prevalence of approximately 97.5/100,000 and were histopathologically confirmed in 170,000 individuals diagnosed in the United States in 2009-2010 (CBTRUS Statistical Report) $)^{3}$.

Although meningiomas are very common tumors in the CNS, data on their epidemiology, clinical characteristics and therapeutic management remain poor. This lack of data can be explained, to some extent, by the benign and frequently silent course of most meningiomas ${ }^{3}$. Meningiomas are more common in females, and their incidence increases with advancing age ${ }^{1}$. In addition to differences in incidence among intracranial tumors in several parts of the world, meningioma patients have distinct geographical and ethnic characteristics, such as the regional and racial incidences at a given age at which the diagnosis is made $e^{3,4,5,6,7}$. Characterization of the demographic and biological aspects of meningioma patients in different regions of the world can provide paths towards understanding the etiology and behavior of these tumors.

We present a cohort of 993 patients with 1104 meningiomas from a single-center institution. These cases were retrospectively analyzed with the purpose of evaluating their clinical and epidemiological factors.

\section{METHODS}

\section{Patient population}

The medical charts of a series of 993 patients with a radiological and/or histopathological diagnosis of CNS meningioma who were consecutively registered at Hospital das Clínicas, Ribeirão Preto Medical School, University of São Paulo (HCFMRP-USP), between May 1984 and December 2019, were retrospectively reviewed. This study was approved by the Research Ethics Committee of our institution. Neuroradiological examinations (computed tomography [CT] and/or magnetic resonance imaging [MRI]) were performed on all the patients, and for those who underwent surgery, histological examinations were added for making the diagnosis. Tumor locations were determined based on CT, MRI and surgery. The histological classification of tumors was carried out in accordance with the $\mathrm{WHO}$ criteria ${ }^{8}$. The demographic data were presented as medians, means, frequencies and percentages and the outcomes as survival rates and as overall survival (OS) and recurrence-free survival (RFS) curves. Patients with grade I meningiomas were followed up yearly, with MRI at one month after surgery and then yearly, and patients with grades II and three were followed up every six months.

The statistical analysis consisted of the chi-square and Fisher exact tests and nonparametric $t$ tests, using the GraphPad Prism 8.0 software. Statistical significance was assumed when $\mathrm{a}=0.05$.

\section{RESULTS}

\section{Demographic profiles}

During the 35-year study period, 993 consecutive patients diagnosed with 1104 meningiomas were followed up at our hospital, representing $43.8 \%$ of all patients with primary brain tumors. Among these, 768 patients underwent surgical treatment. For 225 patients, surgery was not indicated (because the tumors were incidental, non-progressive or calcified; or because the patients were of older age or refused treatment) and these patients did not receive any other kind of treatment. Adjuvant radiotherapy was used in eleven patients ( five WHO grade I, three grade II and three grade III), and in sixteen patients after recurrence/regrowth (six grade I and ten grade II). Sixty-eight patients $(6.8 \%)$ had two or more tumors (9.3\% of non-operated and $6.5 \%$ of operated patients). Patients with multiple tumors underwent one or more surgical procedures, totaling 795 operations for 840 tumors. The distribution of patients according to year over the study period is presented in Figure 1.

Figure 2 presents the distribution of patients according to sex and age. The overall female/male incidence rate for meningiomas was 3.7:1. It was 6.3:1 for the non-operated patients and 3.2:1 for the operated patients ( $\mathrm{p}=0.0271 \mathrm{using}$ paired $t$ test). Females presented meningiomas at an older age than males, among all the patients (mean $55.6 \pm 14.7$ vs. $51.0 \pm 16.4$ years; $p<0.001$ using unpaired $t$ test). and among the operated patients. $(53.0 \pm 13.5$ vs. $50.0 \pm 16.3$ years, $p=$ 0.0102 using unpaired t test).

A peak of meningioma incidence was observed in the 50 to 59-year age group (30.6\%) for both sexes among the operated patients, and $71.5 \%$ of the meningiomas were presented in the $5^{\text {th }}$ and $7^{\text {th }}$ decades of life. For the non-operated patients, there was predominance $(68 \%)$ in the $7^{\text {th }}$ and $9^{\text {th }}$ decades of life (operated vs. non-operated patients; $p=0.0304$ using paired $t$ test), with a peak between 60 and 69 years old (23.1\%). Meningioma occurred in the $1^{\text {st }}$ decade in $0.2 \%(0.5 \%$ for males and $0.13 \%$ for females) and in $1.8 \%$ (4.2\% for males and $1.15 \%$ for females) in the $2^{\text {nd }}$ decade, totaling $2.0 \%$ for these two decades, with predominance among males (1:0.8). The frequency among patients over 70 years old was $16.4 \%$ (36.0\% for non-operated and $10.7 \%$ for operated patients; $\mathrm{p}$ $<0.0001$ using Fisher's exact test) with higher predominance among females (5.8:1), (37.1\% vs. $11.6 \%$; $<0.0001$ using 


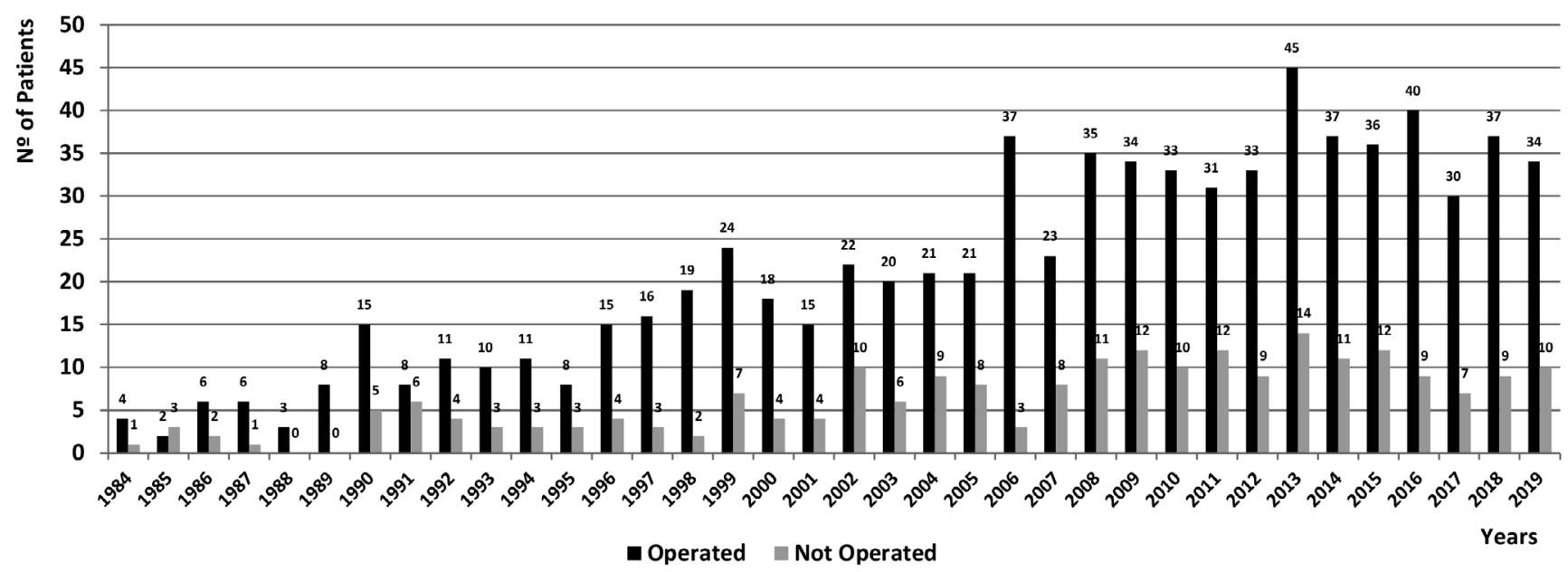

Figure 1. Distribution of patients with a diagnosis of meningioma (993) treated per year at HCFMRP-USP, from 1984 to 2019.

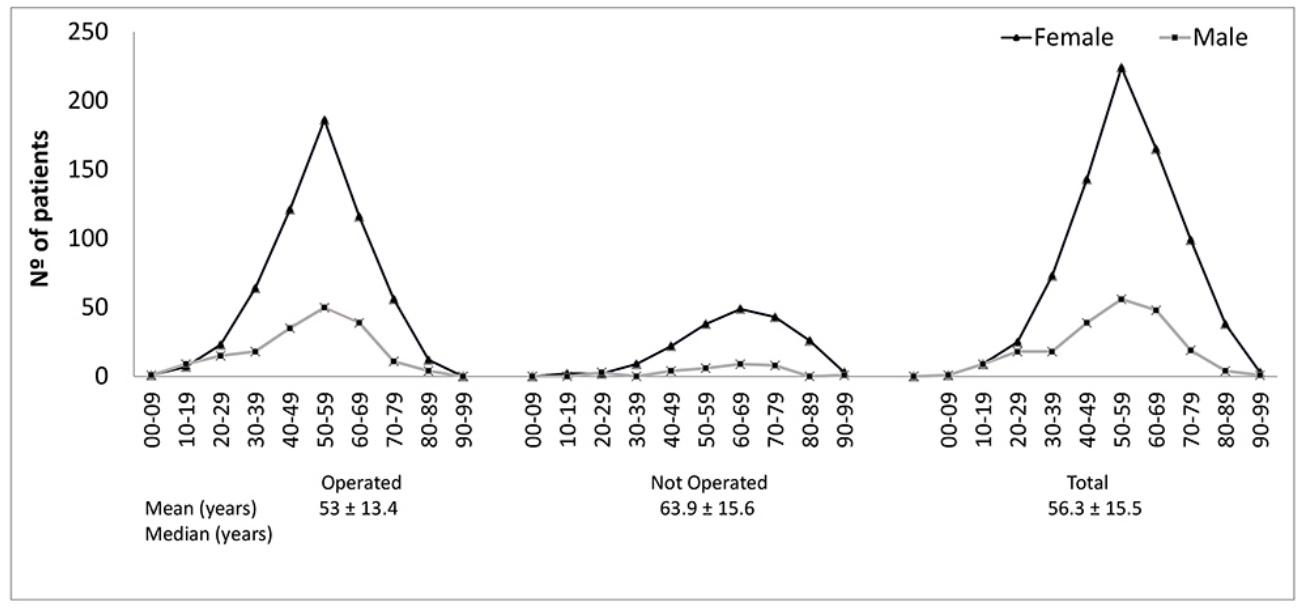

Figure 2. Distribution of patients with a diagnosis of meningioma (993) treated at HCFMRP-USP from 1984 to 2019 , according to age and sex. Operated patients: mean age $=53 \pm 13.5$ years; median $=54$ years. Non-operated patients: mean age $=63.9 \pm 15.6$ years; median age $=64.5$ years. All patients: mean age $=56.3 \pm 15.5$ years; median age $=57$ years.

Fisher's exact test; and 29.0 vs. $8.2 \%$; $\mathrm{p}<0.0087$ using Fisher’s exact test, respectively).

Overall, $87 \%$ of the meningiomas occurred in Caucasians, $12 \%$ in African-Brazilians and $1 \%$ in Asian-Brazilians, with similar distribution between operated and non-operated patients ( $87 \%$ vs. $85.3 \%$ for Caucasians; $12.1 \%$ vs. $13.3 \%$ for African-Brazilians; and $0.9 \%$ vs. $1.3 \%$ for Asian-Brazilians, respectively). Based on the racial distribution of the population of the state of São Paulo in 2019 (Brazilian Institute for Geography and Statistics, IBGE, 2010) ${ }^{9}$, meningiomas predominated among Caucasians, compared with AfricanBrazilian and Asian-Brazilian patients ( $p<0.0001$, using chisquare test).

\section{Tumor location}

Table 1 summarizes the anatomical distribution of these 1104 meningiomas in 993 patients. Meningiomas were located in the cranial cavity in $96.6 \%$ (22\% in the cerebral convexity, $18.3 \%$ in the parasagittal region, $1.2 \%$ in the ventricles and $58.5 \%$ in the skull base). We did not find any association between sex and topographic location (convexity vs. skull base and parasagittal region vs. skull base; $p=0.0834$ using chi-square test with Yates' correction; and $\mathrm{p}=0.2179$ using Fisher's exact test respectively). Spinal canal meningiomas were observed in $3.5 \%$ of the patients, with predominance in females (4.4:1), and most were located in the dorsal region (65.8\%).

\section{Histopathological features}

The histopathological distribution of the operated meningiomas is summarized in Table 2. WHO grade I occurred in $88.9 \%$, grade II in $9.9 \%$ and grade III in $1.2 \%$. Females predominated among the WHO grade I patients (3.8:1), and there was no predominant sex with regard to patients with grades II (1.02:1) and III (1:1) ( $p=0.001$ and $p=0.0411$, respectively, using Fisher's exact test).

The most frequent grade I histological subtypes were transitional (39.3\%) and meningothelial (28.8\%); $91.5 \%$ of grade II cases were atypical and $50 \%$ of grade III cases were anaplastic. In the spinal canal, all the tumors were grade I; most of 
them were transitional (44.4\%), followed by psammomatous and meningothelial tumors.

\section{Treatment and outcome}

The treatment of the 840 meningiomas (surgical or surgical + adjuvant treatment), the OS/RFS curves and the mortality rates are shown in Table 3 and in Figure 3. There was no significant difference in the OS/RFS curves between the patients with intracranial and spinal meningiomas. There was no significant difference in the OS curves between patients who underwent total or Simpson's grades I and II resection vs. subtotal or Simpson's grades III-IV resection. The RFS curves were better for patients who underwent total or Simpson's grades I and II resection than for those who underwent subtotal or Simpson's grades III-IV resection ( $p<0.0001$ using Mantel-Cox log-rank test, for both). There was no difference between the supratentorial and skull base locations (Figure 4). There were significant differences in OS/RFS between WHO grades I vs. II vs. III (Figure 5).

\section{Risk factors}

Meningiomas occurring after radiotherapy to treat other tumors were observed in six patients $(0.6 \%$ of the total number of tumors and $0.78 \%$ of the operated patients), of whom five were male and one was female. Two patients (33.3\%) had multiple tumors. These patients were diagnosed 8 to 16 years after radiotherapy. Four of these patients were classified as WHO grade II and two as grade I.

Table 4 summarizes the association between meningiomas and neurofibromatosis type 2 (NF2). NF2 was detected in $3.1 \%$ of the patients with meningiomas, with similar distribution between the operated and non-operated patients, and

Table 1. Distribution of meningiomas (1104) in 993 patients treated at HCFMRP-USP from 1984 to 2019, according to the location in the central nervous system and sex.

\begin{tabular}{|c|c|c|c|c|c|c|c|c|c|}
\hline \multirow[t]{2}{*}{ Location } & \multicolumn{3}{|c|}{ Operated patients } & \multicolumn{3}{|c|}{ Non-operated patients } & \multicolumn{3}{|c|}{ Total } \\
\hline & Female & Male & Total & Female & Male & Total & Female & Male & Total \\
\hline \multicolumn{10}{|l|}{ Intracranial } \\
\hline Convexity & 114 & 40 & 154 & 71 & 9 & 80 & 185 & 49 & $234(21.9 \%)$ \\
\hline Superior sagittal sinus & 87 & 42 & 129 & 25 & 5 & 30 & 112 & 47 & $159(14.9 \%)$ \\
\hline Falx & 16 & 6 & 22 & 10 & 4 & 14 & 26 & 10 & 36 \\
\hline Ventricles & 7 & 4 & 11 & 2 & 0 & 2 & 9 & 4 & 13 \\
\hline \multicolumn{10}{|l|}{ Skull base } \\
\hline Sphenoid wing & 91 & 21 & 112 & 24 & 4 & 28 & 115 & 25 & $140(13.1 \%)$ \\
\hline Tentorial & 58 & 14 & 72 & 20 & 2 & 22 & 78 & 16 & 94 \\
\hline Tuberculum sellae & 55 & 15 & 70 & 12 & 1 & 13 & 67 & 16 & 83 \\
\hline Olfactory groove & 35 & 8 & 43 & 15 & 2 & 17 & 50 & 10 & 60 \\
\hline Petrous & 29 & 7 & 36 & 7 & 2 & 9 & 36 & 9 & 45 \\
\hline Spheno-orbital & 30 & 4 & 34 & 4 & 0 & 4 & 34 & 4 & 38 \\
\hline Foramen magnum & 18 & 3 & 21 & 5 & 0 & 5 & 23 & 3 & 26 \\
\hline Petroclival & 11 & 8 & 19 & 3 & 2 & 5 & 14 & 10 & 24 \\
\hline Sphenopetroclival & 15 & 4 & 19 & 6 & 4 & 10 & 16 & 8 & 24 \\
\hline Cavernous sinus & 12 & 5 & 17 & 11 & 2 & 13 & 23 & 7 & 30 \\
\hline Middle fossa & 10 & 4 & 14 & 0 & 0 & 0 & 10 & 4 & 14 \\
\hline Optic Nerve/Canal & 12 & 4 & 4 & 1 & 1 & 2 & 6 & 5 & 11 \\
\hline Others & 18 & 4 & 22 & 6 & 0 & 6 & 24 & 4 & 28 \\
\hline Total skull base & 387 & 101 & 488 & 116 & 20 & 136 & 503 & 121 & $624(58.4 \%)$ \\
\hline Total intracranial & 611 & 193 & 804 & 224 & 38 & 262 & 835 & 221 & $1066(96.6 \%)$ \\
\hline \multicolumn{10}{|l|}{ Spinal canal } \\
\hline Cervical & 6 & 3 & 9 & 0 & 0 & 0 & 6 & 3 & 9 \\
\hline Cervicodorsal & 2 & 0 & 2 & 1 & 0 & 1 & 2 & 0 & 3 \\
\hline Dorsal & 20 & 3 & 23 & 0 & 0 & 0 & 20 & 3 & 23 \\
\hline Dorsolumbar & 2 & 0 & 2 & 0 & 0 & 0 & 2 & 0 & 2 \\
\hline Not specified & 0 & 0 & 0 & 0 & 1 & 1 & 1 & 0 & 1 \\
\hline Total spinal & 30 & 6 & 36 & 1 & 1 & 2 & 31 & 6 & $38(3.4 \%)$ \\
\hline Total intracranial (+ spinal) & 641 & 199 & 840 & 225 & 39 & 264 & 866 & 228 & 1104 (100\%) \\
\hline
\end{tabular}


Table 2. Histopathological subtypes of meningiomas in 840 tumors among 768 operated patients at HCFMRP-USP from 1984 to 2019.

\begin{tabular}{|c|c|c|c|c|c|c|c|c|c|}
\hline \multirow[t]{2}{*}{ Location } & \multicolumn{3}{|c|}{ Intracranial } & \multicolumn{3}{|c|}{ Spinal canal } & \multicolumn{3}{|c|}{ Total } \\
\hline & Female & Male & Total & Female & Male & Total & Female & Male & Total \\
\hline \multicolumn{10}{|l|}{ Grade I } \\
\hline Transitional & 227 & 60 & 287 & 13 & 3 & 16 & 240 & 63 & 303 \\
\hline Meningothelial & 163 & 49 & 212 & 6 & 2 & 8 & 169 & 51 & 220 \\
\hline Fibroblastic & 58 & 12 & 70 & 2 & & 2 & 60 & 12 & 72 \\
\hline Psammomatous & 28 & 5 & 33 & 9 & & 9 & 37 & 5 & 42 \\
\hline Meningioma & 23 & 6 & 29 & & & & 23 & 6 & 29 \\
\hline Syncytial & 19 & 2 & 21 & & & & 19 & 2 & 21 \\
\hline Angiomatous & 16 & 4 & 20 & & & & 16 & 4 & 20 \\
\hline Microcystic & 13 & 1 & 14 & & & & 13 & 1 & 14 \\
\hline Mixed & 9 & 2 & 11 & & & & 9 & 2 & 11 \\
\hline Secretory & 8 & 2 & 10 & & & & 8 & 2 & 10 \\
\hline Lymphoplasmacyte-rich & 1 & 1 & 2 & & & & 1 & 1 & 2 \\
\hline Metaplastic & 1 & 0 & 1 & & 1 & 1 & 1 & 1 & 2 \\
\hline Lipoblastic & 0 & 1 & 1 & & & & 0 & 1 & 1 \\
\hline Total grade I & 566 & 145 & 711 & 30 & 6 & 36 & 596 & 151 & 747 \\
\hline \multicolumn{10}{|l|}{ Grade II } \\
\hline Atypical & 37 & 39 & 76 & & & & 37 & 39 & 76 \\
\hline Chordoid & 2 & 2 & 4 & & & & 2 & 2 & 4 \\
\hline Clear cell & 3 & 0 & 3 & & & & 3 & 0 & 3 \\
\hline Total grade II & 42 & 41 & 83 & & & & 42 & 41 & 83 \\
\hline \multicolumn{10}{|l|}{ Grade III } \\
\hline Anaplastic & 2 & 3 & 5 & & & & 2 & 3 & 5 \\
\hline Papillary & & & 1 & & & & & 1 & 1 \\
\hline Rhabdoid & 3 & 1 & 4 & & & & 3 & 1 & 4 \\
\hline Total grade III & 5 & 5 & 10 & & & & 5 & 5 & 10 \\
\hline Total & 613 & 191 & 804 & 30 & 6 & 36 & 643 & 197 & 840 \\
\hline
\end{tabular}

Table 3. Treatment and outcomes among 840 meningiomas treated at HCFMRP-USP from 1984 to 2019.

\begin{tabular}{lc}
\hline Treatment & $N^{\circ}(\%)$ \\
\hline Extent of resection & $634(75.5 \%)$ \\
\hline Gross total resection & $180(21.4 \%)$ \\
\hline Subtotal resection & $24(2.9 \%)$ \\
\hline Partial & $2(0.2 \%)$ \\
\hline Biopsy & $480(57.3 \%)$ \\
Simpson grade I & $149(17.7 \%)$ \\
Simpson grade II & $6(0.7 \%)$ \\
\hline Simpson grade III & $201(23.9 \%)$ \\
Simpson grade IV & $3(0.4 \%)$ \\
\hline Simpson grade V & $11(1.3 \%)$ \\
\hline Adjuvant conventional radiotherapy & $1-426$ months \\
\hline Follow-up & $84 \pm 73.1$ months \\
\hline Range & 67 months \\
\hline Mean & \\
\hline Median & \\
\hline
\end{tabular}


Table 3. Cont.

\begin{tabular}{|c|c|}
\hline Treatment & $\mathrm{N}^{\circ}(\%)$ \\
\hline \multicolumn{2}{|l|}{ Outcome } \\
\hline \multicolumn{2}{|l|}{ Survival rates } \\
\hline 5 years & $91.2 \%$ \\
\hline 10 years & $82.9 \%$ \\
\hline 15 years & $78.2 \%$ \\
\hline 20 years & $72.5 \%$ \\
\hline 30 years & $40.4 \%$ \\
\hline \multicolumn{2}{|l|}{ Recurrence } \\
\hline Recurrence rate (all follow-up) & $135(16.1 \%)$ \\
\hline \multicolumn{2}{|l|}{ Recurrence-free estimates } \\
\hline 5 years & $94.5 \%$ \\
\hline 10 years & $83.4 \%$ \\
\hline 15 years & $64 \%$ \\
\hline 20 years & $51.6 \%$ \\
\hline 30 years & $30.7 \%$ \\
\hline \multicolumn{2}{|l|}{ Mortality } \\
\hline Overall (over the follow-up period) & $127(15.1 \%$ \\
\hline 1 month (mortality due to operation) & $32(3.8 \%)$ \\
\hline $2^{\text {nd }}-12^{\text {th }}$ months & $13(1.5 \%)$ \\
\hline $13^{\text {th }}-180^{\text {th }}$ months & $73(8.7 \%)$ \\
\hline $181^{\text {st }}-426^{\text {th }}$ months & $9(1.1 \%)$ \\
\hline
\end{tabular}

Table 4. Distribution of patients with neurofibromatosis 2 among patients with a diagnosis of meningioma who were treated at HCFMRP-USP from 1984 to 2019.

\begin{tabular}{|c|c|c|c|c|c|c|c|c|c|}
\hline \multirow[t]{2}{*}{ Treatment } & \multicolumn{2}{|c|}{ Non-operated } & \multicolumn{4}{|c|}{ Operated } & \multicolumn{3}{|c|}{ Total } \\
\hline & Female & Male & Total & Female & Male & Total & Female & Male & Total \\
\hline \multicolumn{10}{|c|}{ Number of tumors/NF2 } \\
\hline One & 5 & 5 & $\begin{array}{c}6 \\
(2.9 \%)\end{array}$ & $\begin{array}{c}7 \\
(0.7 \%)\end{array}$ & $8(4.6 \%)$ & $\begin{array}{c}15 / 721 \\
(2.1 \%)\end{array}$ & 12 & 9 & $\begin{array}{c}21 / 925 \\
(2.3 \%)\end{array}$ \\
\hline Multiple & 1 & 0 & $\begin{array}{c}1 \\
(4.7 \%)\end{array}$ & $\begin{array}{c}5 \\
(10.4 \%)\end{array}$ & $\begin{array}{c}9 / 47 \\
(19.1 \%)\end{array}$ & $\begin{array}{c}9 / 47 \\
(19.1 \%)\end{array}$ & $6 / 53$ & $4 / 15$ & $\begin{array}{c}10 / 68 \\
(14.7 \%)\end{array}$ \\
\hline Total & 6 & 1 & $\begin{array}{l}7 / 225 \\
(3.1 \%)\end{array}$ & $\begin{array}{c}12 \\
(2.5 \%)\end{array}$ & $\begin{array}{c}12 \\
(6.6 \%)\end{array}$ & $\begin{array}{c}24 / 768 \\
(3.1 \%)\end{array}$ & $18 / 780 *$ & $13 / 213^{*}$ & $\begin{array}{c}31 / 993 \\
(3.1 \%)\end{array}$ \\
\hline
\end{tabular}

* Significant difference, $p=0.0121$, using Fisher's exact test.

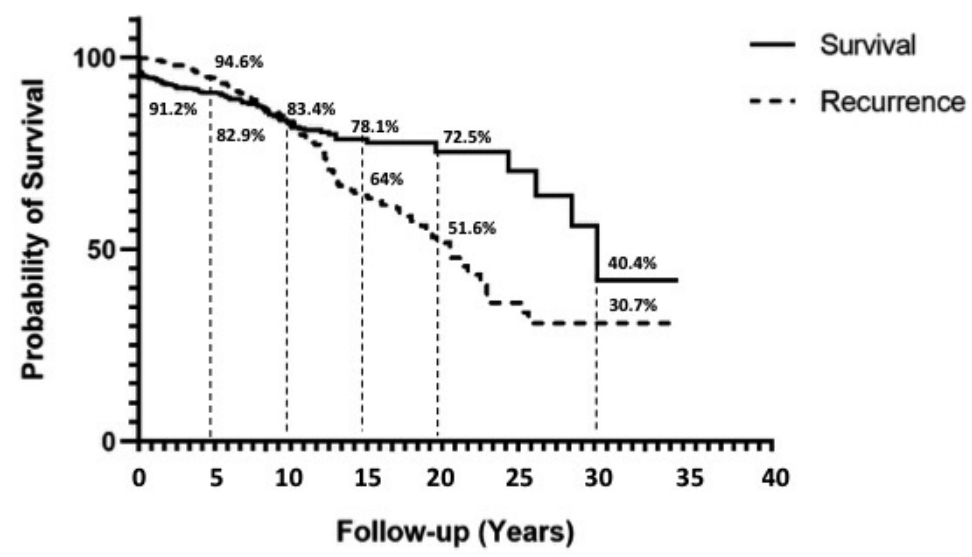

Figure 3. Survival curve for patients with meningiomas who underwent surgical treatment (840 cases) at HCFMRP-USP. Percentages represent the estimates for overall survival and survival free recurrence rates after 1, 10, 15, 20 and 30 years of follow-up. 


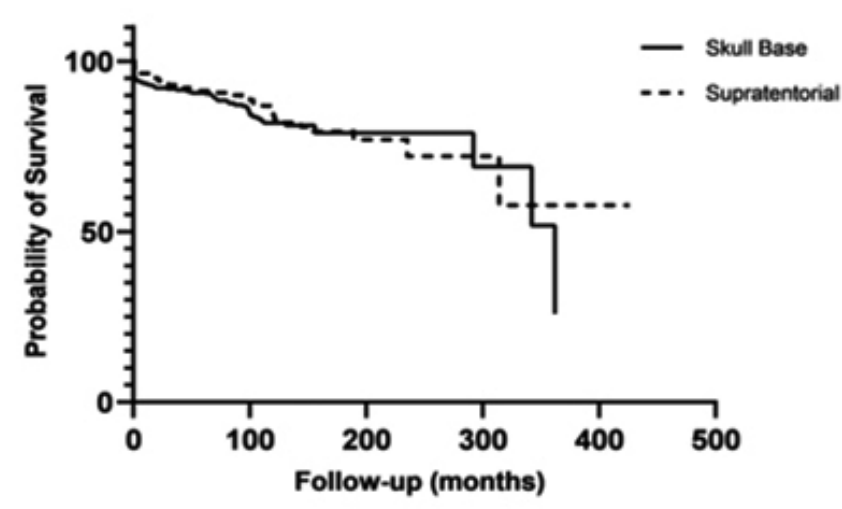

A

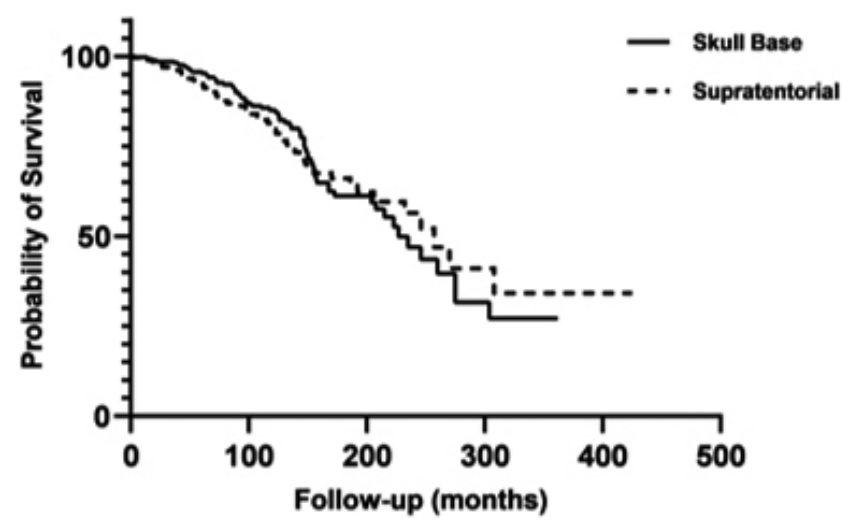

B

Figure 4. Overall survival (A) and recurrence-free survival (B) curves for patients with meningiomas who underwent operations (840 cases) according to the location: supratentorial vs. skull base (follow-up: 1-426 months; mean = 77 months; median = 61.5 months). No significant differences ( $p=0.4163$ and $p=07866$, using Mantel-Cox log-rank test, respectively).

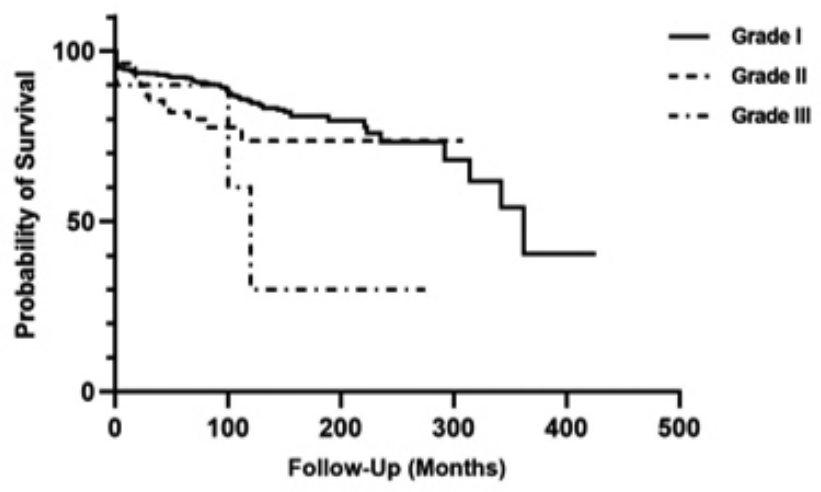

A

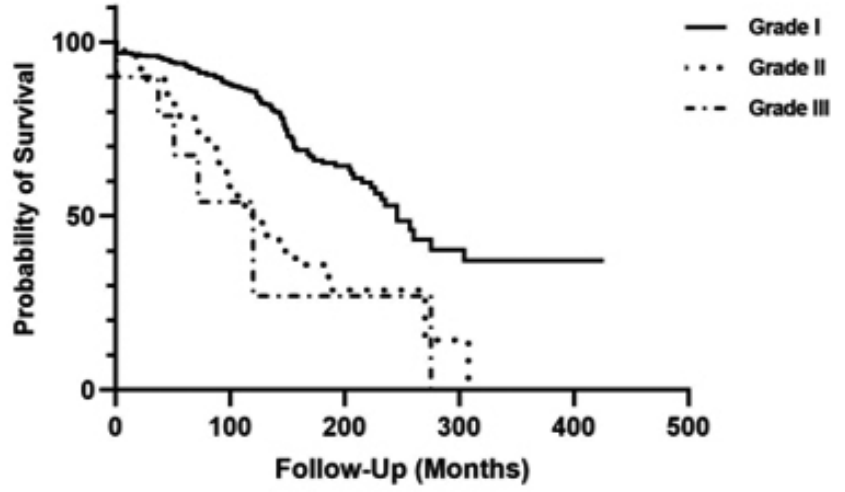

B

Figure 5. Overall survival (A) and recurrence-free survival (B) curves for patient with meningiomas who underwent operations (840 cases) according to WHO grades (follow-up: 1-426 months; mean = 77 months; median = 61.5 months). Significant differences for I vs. II vs. III ( $p=0.0301$ and $p=0.0001$, using Mantel-Cox log-rank test, respectively); for I vs II (for OS curves, $p=0373$, using Mantel-Cox log-rank test); and for I vs III and II vs III (for RFS curves, $p=0.0008$ and $p=0.0001$, using Mantel-Cox log-rank test, respectively).

with predominance among males $(6.1 \%$ in males vs. $2.3 \%$ in females). NF2 was observed in $31.8 \%$ of the patients with multiple meningiomas, with predominance among males (25\% in males vs. $10.9 \%$ in females).

\section{DISCUSSION}

\section{Demographic profiles}

Meningiomas are the most common intracranial extraaxial neoplasms. Population-based studies have shown that the prevalence of histopathologically confirmed meningioma cases per year per 100,000 inhabitants was estimated to be approximately 97.5 in the United States (CBTRUS Statistical Report $)^{3}$. The incidence of meningiomas among CNS tumors in the United States is $36.8 \%$, and the incidence is more than twice as high in females as in males (8.36/100,000 and $3.61 / 100,000$ people, respectively, per year). Among these meningiomas, $79 \%$ of them were located in the skull, $4.2 \%$ were in the spinal canal and $16 \%$ did not have a specified location $^{3}$. Meningioma lesions are common ${ }^{1,8}$, with incidences ranging from $5.4 \%$ to $8.9 \%$ according to the origin of the series analyzed (population, surgical, CT or autopsy) ${ }^{8,10-13}$. We observed that $7.0 \%$ of the patients in our cohort had multiple tumors, predominantly among the non-operated patients (9.8\% vs. $6.2 \%)$.

Due to the lack of prospective databases, the epidemiology of meningiomas in developing and underdeveloped countries is based on retrospective analysis on data from hospitalized operated patients or from autopsy series. Therefore, these data do not reflect the actual situation of this type of 
tumor in the population. From the scarce epidemiological information, meningiomas had lower incidence in China than in Japan or in Western countries ${ }^{2,14-16}$. In addition, some characteristics were common to many regions. For example, meningiomas were always the most or second most frequent CNS tumor, occurred predominantly in women, had higher incidence in the $4^{\text {th }}$ to $6^{\text {th }}$ decades of life and consisted mostly of benign tumors ${ }^{4-6}$, in South America ${ }^{17,18}$, Asia ${ }^{15,16}$, Europe ${ }^{19,20}$ and the Middle East ${ }^{21,22}$.

In Brazil, two studies, one using a surgical/necropsy series and the other using data from neurosurgical centers, showed meningioma incidences of $19 \%$ and $22.6 \%$ respectively among primary intracranial tumors, with mean ages of 40 and 45.8 years. Cases occurred predominantly between 20 and 50 years of age (peak in the $5^{\text {th }}$ decade of life) and predominantly among females (2.2:1). 96.7\% were located in the intracranial region and $3.29 \%$ in the spinal canal ${ }^{17,18}$.

Our series was from a single-center public tertiary-level hospital in the state of São Paulo affiliated to the Brazilian National System Health (SUS), which is responsible for treating a population of approximately 5,000,000 inhabitants. To obtain a better approximation of the population data, this series was divided into two groups: patients who underwent surgical treatment and patients with a radiological diagnosis of meningioma who remained non-operated for several reasons, such as older age, small tumor size, incidental tumors with no edema in the adjacent nervous tissue, poor clinical conditions and the patient's refusal of treatment.

The incidence of this tumor progressively increased from 1984 until it stabilized in recent years. This can be explained by better access to SUS and improving access to neuroradiological investigations, which has led to an increased rate of diagnosis of incidental meningiomas, especially in the past two decades. Additionally, the Division of Neurosurgery of HCFMRP-USP has acquired expertise for treatment of patients with CNS meningiomas and has become a recognized regional reference center for treating these patients from SUS.

The incidence of meningiomas increases with age, and their occurrence is predominantly in the $5^{\text {th }}$ to $7^{\text {th }}$ decades of life $\mathrm{e}^{3,6,7,18,19,23}$. In some countries, such as $\mathrm{China}^{15}$, South Africa $^{5}$ and other parts of Brazil ${ }^{17,18}$, higher incidences among younger patients were observed. In agreement with most other authors, meningiomas predominated in our patients between the $5^{\text {th }}$ and $7^{\text {th }}$ decades of life (67\% of cases), with a peak in the $6^{\text {th }}$ decade $(18.2 \%)$. Among the non-operated patients, the cases occurred predominantly between the $6^{\text {th }}$ and $8^{\text {th }}$ decades $(68 \%)$, with a peak in the $7^{\text {th }}$ decade $(25.2 \%)$. The discrepancy observed in relation to other regions of Brazil can be explained by the different ethnic composition in distinct parts of the country. Improved access to neuroradiological investigations has resulted in an increasing number of diagnoses of intracranial meningiomas in older patients with no symptoms or stable minimal symptoms, which do not need surgical treatment.

The occurrence rates of meningiomas in the $1^{\text {st }}$ and $2^{\text {nd }}$ decades of life were low and similar to what has been reported in the literature $\mathrm{e}^{2,3,8,17}$, with predominance among males. Over the age of 70 , the incidence was $16.4 \%$, with a 5.8:1 predominance among females. A trend towards reduction and even inversion of the female/male ratio during childhood and towards an increase of male patients in old age has been reported in the literature ${ }^{3,24}$. We observed that the female/male ratio was twice as large among the non-operated patients (6.3:1), and that the male patients had their meningiomas diagnosed earlier (six years earlier) than the females, which was also observed in South Africa ${ }^{6}$.

Higher frequency of meningiomas among black Africans and individuals of African-American descent has been reported in the literature ${ }^{3-6}$. Other authors reported similar distribution ${ }^{1}$, while others observed that the annual incidence was lower among individuals of African-American descent than among Caucasians, and that Hispanic patients had their tumors diagnosed at a younger age than Caucasians ${ }^{7}$. Based on the ethnic distribution of the population of the state of São Paulo from the last Brazilian census $(2010)^{9}$, meningiomas predominated among Caucasians, compared with AfricanBrazilians and Asian-Brazilians ( $p<0.0001$ using chi-square test).

\section{Location}

Meningiomas are more frequently found in the intracranial compartment ( 80.7 to $96.7 \%)^{3,8,18,21,23,25,26}$. They occur predominantly in the convexity, parasagittal region and sphenoid wing, and this last region harbors more than half of them ${ }^{8,20,21,25,26}$. In the spinal canal, the incidences of meningiomas have ranged from 4.2 to $19.3 \%^{3,18,21,25,26}$, and most of them have been found in the dorsal region $(69.6 \%)^{8,15,23,26}$, with predominance among females ${ }^{8,26}$. Our observations are in agreement with data from the literature, which have shown predominance of the transitional subtype among intracranial tumors. We did not find any significant difference in intracranial tumor location according to sex (convexity vs. skull base; and parasagittal region vs. skull base). We observed higher incidence of tumors in the skull base (58\%) than what was observed by others ${ }^{21,23}$, and this can be explained by the fact that our institution is a reference center for these tumors.

\section{Histopathological features}

Most meningiomas are benign tumors of WHO grade I (79-95\%), and a smaller number are grade II and III tumors (20-30\%). Predominance of grade I tumors in females ( female/male ratios ranging from 2:1: to 13;1:) has commonly been reported in the literature ${ }^{1,3,4.6-8,14,15,17-21,26,27}$. However, the incidence becomes equal between the sexes at WHO 
grades II and $\mathrm{III}^{3,8,26}$ and in patients under 20 years old ${ }^{26}$, and the difference increases among patients over 70 years old ${ }^{27}$. Meningothelial and transitional histological subtypes predominate among tumors located in the intracranial compartment; and the meningothelial subtype, followed by the psammomatous subtype, predominates in the spinal canal ${ }^{21,26}$. Our data are in agreement with the literature regarding histopathological distribution (88.9\% of our patients had grade I tumors) and the female/male ratios for grade I (3.7:1), grade II (1.02:1) and grade III (1:1) tumors, and with predominance of the transitional subtype among intracranial tumors and among tumors of the spinal canal.

\section{Treatment and outcomes}

Meningiomas are generally treated with surgery. The extent of resection and histopathological grade are the strongest prognostic factors for meningioma treatment. Age, sex and tumor location are other more debatable factors. Total resection or Simpson I and II ranges are achieved in 77 to $84 \%$ of the cases and subtotal resection or Simpson III and IV in 15 to $87 \%^{19,20,24,25,28-30}$. Patients undergoing more extensive resections and with WHO grade I tumors have better survival rates and lower recurrence rates ${ }^{20,24,25,28-31}$. Mortality due to the operation ranges from 2 to $16 \%$ and the overall mortality rate after 15 years of follow-up ranges from 20 to $29 \%^{19,20,24,28,29}$. The 5 and 10-year survival rates vary from 79 to $90 \%$ and 78 to $81 \%$, respectively; beyond 15 years of follow-up, the rates range from 23 to $69 \%^{19,20,24,29}$. The recurrence rates after 5 years and after 15 years range respectively from 7 to $31 \%$ and 19 to $32 \%^{19.28-31}$. Our resection and mortality rates were in agreement with the literature and our survival (78.2\%) and RFS $(64 \%)$ rates at 15 years were better than the levels reported in the literature. We found that there was no difference in survival in relation to the extent of resection, as also reported in a recent study using data from CBTRUS (United States) ${ }^{23}$.

\section{Risk factors}

The most important risk factors for meningiomas are exposure to ionizing radiation, hormones, genetic changes and head trauma ${ }^{1,2,8}$. Exposure to ionizing radiation increases the risk of developing intracranial tumors and, specifically for meningiomas, ionizing radiation increases the risk six to tenfold ${ }^{1,2,32}$. These radiation doses might consist of low doses such as irradiation for tinea capitis treatment ${ }^{33}$, panoramic dental radiographs ${ }^{34}$ or radiotherapy for intracranial tumors, ${ }^{35}$ and going up to the radiation produced by the atomic bomb $b^{36}$. Meningiomas occurring after intracranial tumor irradiation are often multiple and more aggressive, with higher histopathological grades and recurrence rates, and are associated with complex cytogenetic aberrations ${ }^{8-36}$. There is also evidence that radiotherapy causes or accelerates the progression of meningiomas from less severe to more aggressive grades ${ }^{37,38}$. Our data corroborated these findings; $33.3 \%$ of our patients had multiple tumors, and $66.7 \%$ of these tumors were atypical and were predominantly in males (5:1).

People with specific mutations in the NF2 gene are at increased risk of developing meningiomas, and tend to develop them at an earlier age ${ }^{2,3,8}$. It is also well known that patients with meningiomas develop classic NF2 ${ }^{39}$. Multiple meningiomas are associated with NF2 in 0 to $20 \%$ of patients ${ }^{8,11,12}$. The association of multiple meningiomas with NF2 that we observed in this series (3.1\%) was similar between the operated and non-operated patients, and was predominantly in males. These data were similar to what has been reported in the literature; however, the association of NF2 with multiple meningiomas $(31.8 \%)$ and the predominance in males were much higher than previous reported.

In conclusion, although meningiomas are the most common brain tumor, only a few epidemiological studies have been published. An increase in the incidence of primary brain tumors in general, and of meningiomas in particular, has been observed in the past decades in several countries. Our study showed higher incidence of meningiomas in a regional population in the state of São Paulo, Brazil, than in the literature. Among the non-operated patients, predominance in females and older age were significant factors. There was predominance in Caucasian patients, compared with AfricanBrazilian and Asian-Brazilian patients. The association with NF2 among patients with multiple meningiomas was higher than previous reported, and the predominance in males among these patients was not previously reported in the literature. The differences observed between our data and those of other Brazilian studies can be attributed to the different ethnic compositions of the populations in different regions of Brazil.

\section{REFERENCES}

1. Claus EB, Bondy ML, Schildkraut JM, Wiemels JL, Wrensch M, Black PM. Epidemiology of intracranial meningioma. Neurosurgery. 2005 Dec 1;57(6):1088-95. https://doi.org/10.1227/01. NEU.0000188281.91351.B9

2. Wiemels J, Wrensch M, Claus EB. Epidemiology and etiology of meningioma. J Neurooncol. 2010 Sep;99(3):307-14. https://doi. org/10.1007/s11060-010-0386-3
3. Ostrom QT, Cioffi G, Gittleman H, Patil N, Waite K, Kruchko C, et al. CBTRUS Statistical report: primary brain and other central nervous system tumors diagnosed in the United States in 2012-2016. Neuro Oncol. 2019 Nov 1;21(5 Suppl 5):v1-100. https://doi.org/10.1093/ neuonc/noz150

4. Ohaegbulam SC. Geographical neurosurgery. Neurol Res. 1999 Mar;21(2):161-70. https://doi.org/10.1080/01616412.1999.11740912 
5. Ibebuike K, Ouma J. Demographic profile of patients diagnosed with intracranial meningiomas in two academic hospitals in Johannesburg, South Africa: a 12-month prospective study. Afr Health Sci. 2014 Dec;14(4):939-45. https://doi.org/10.4314/ahs. v14i4.24

6. Dolecek TA, Dressler EVM, Thakkar JP, Liu M, Al-Qaisi A, Villano JL. Epidemiology of meningiomas post Public Law 107-206: the benign brain tumor cancer registries act. Cancer. 2015 Jul 15;121(14):240010. https://doi.org/10.1002/cncr.29379

7. Anzalone CL, Glasgow AE, Van Gompel JJ, Carlson ML. Racial differences in disease presentation and management of intracranial meningioma. J Neurol Surg B Skull Base. 2019 Dec;80(6):555-61. https://doi.org/10.1055/s-0038-1676788

8. Perry A, Louis DN, Scheitauer BW, Budka H, von Deimling A. Meningiomas. In Louis DN, Ohgaki H, Wiestler OD, Cavenee WK., editors. World health organization of classification of tumours. 3rd ed. Lyon:YARC Press; 2007. p. 164-72.

9. IBGE [Internet]. População. Brasília: Instituto Brasileiro de Geografia e Estatítica; [cited 2020 Sept 01]. Available from: https://www.ibge. gov.br/estatisticas/sociais/populacao.html

10. Nakasu S, Hirano A, Shimura T, Llena JF. Incidental meningiomas in autopsy study. Surg Neurol. 1987 Apr;27(4):319-22. https://doi. org/10.1016/0090-3019(87)90005-X

11. Butti G, Assietti R, Casalone R, Paoletti P. Multiple meningiomas: a clinical, surgical, and cytogenetic analysis. Surg Neurol. 1989 Apr;31(4):255-60. https://doi.org/10.1016/0090-3019(89)90048-7

12. Antinheimo J, Sankila R, Carpén O, Pukkala E, Sainio M, Jääskeläinen J. Population-based analysis of sporadic and type 2 neurofibromatosis associated meningiomas and schwannomas. Neurology. 2000 Jan 11;54(1):71-6. https://doi.org/10.1212/ WNL.54.1.71

13. Lynch JC, Ferreira LAS, Welling L, Schulz RC. Multiple intracranial meningiomas: diagnosis, biological behavior and treatment. Arq Neuropsiquiatr. 2008 Sep;66(3B):702-7. https://doi.org/10.1590/ S0004-282X2008000500018

14. Rohringer M, Sutherland GR, Louw DF, Sima AA. Incidence and clinicopathological features of meningioma. J Neurosurg. 1989 Nov;71(5):665-72. https://doi.org/10.3171/jns.1989.71.5.0665

15. Wen-qing $H$, Shi-ju Z, Qing-sheng T, Jian-qing H, Yu-xia L, Qing-zhong $X$, et al. Statistical analysis of central nervous system tumors in China.J Neurosurg. 1982 Apr;56(4):555-64. https://doi.org/10.3171/ jns.1982.56.4.0555

16. Kuratsu J, Kochi M, Ushio Y. Incidence and clinical features of asymptomatic meningiomas. J Neurosurg. 2000 May;92(5):766-70. https://doi.org/10.3171/jns.2000.92.5.0766

17. Lana-Peixoto MA, Pittella JEH, Arouca EMG. Tumores primários intracranianos. analise de uma série de autopsias e biopsias consecutivas. Arq Neuropsiquiatr. 1981 Mar;39(1):13-24. https://doi. org/10.1590/S0004-282X1981000100002

18. Torres LFB, Madalozzo LE, Werner B, de Norronha L, Jacob GVV, Medeiros BC, et al. Meningiomas: estudo epidemiológico e anátomopatológico de 304 casos. Arq Neuropsiquiatr. 1996 Dec;54(4):549-56. https://doi.org/10.1590/S0004-282X1996000400001

19. Sankila R, Kallio M, Jääskeläinen J, Hakulinen T. Long-term survival of 1986 patients with intracranial meningioma diagnosed from 1953 to 1984 in Finland. Comparison of the observed and expected survival rates in a population-based series. Cancer. 1992 Sep 15;70(6):156876. https://doi.org/10.1002/1097-0142(19920915)70:6<1568::AIDCNCR2820700621>3.0.CO;2-Y

20. Kallio M, Sankila, R, Hakulinen, T, Jääskeläinen J. Factors affecting operative and excess long-term mortality in 935 patients with intracranial meningioma. Neurosurgery. 1992 Jul;31(1):2-12. https:// doi.org/10.1227/00006123-199207000-00002

21. Abdelzaher E, El Deeb NMF, Gowil AG, Yehya A. Biological and demographic profile of meningiomas in a cohort of Egyptian patients: impact on tumor recurrence. Scientific World Journal. 2013 Dec 26;2013:375139. https://doi.org/10.1155/2013/375139

22. Rami A, Suzan E, Rafeed A, Nooruddeen AM, Lamees A, Duaa A, et al. The sovereignty of primary Cranial-Tumors Meningiomas: vetting the cardinal epidemiological features. Med Arch. 2018 Dec;72(6):434-8. https://doi.org/10.5455/medarh.2018.72.434-438

23. Achey RL, Gittleman H, Schroer J, Khanna V, Kruchko C, BarnholtzSloan JS. Nonmalignant and malignant meningioma incidence and survival in the elderly, 2005-2015, using the Central Brain Tumor Registry of the United States. Neuro Oncol. 2019 Feb 19;21(3):38091. https://doi.org/10.1093/neuonc/noy162

24. Sicking J, Voß KM, Spille DC, Schipmann S, Holling M, Paulus W, et al. The evolution of cranial meningioma surgery a single-center 25-year experience. Acta Neurochir (Wien). 2018 Sep;160(9):1801-12. https:// doi.org/10.1007/s00701-018-3617-6

25. Brodbelt AR, Barclay ME, Greenberg D, Williams M, Jenkinson MD, Karabatsou K. The outcome of patients with surgically treated meningioma in England: 1999-2013. A cancer registry data analysis. Br J Neurosurg. 2019 Dec;33(6):641-7. https://doi.org/10.1080/02688 697.2019 .1661965

26. Mubeen B, Makhdoomi R, Nayil K, Rafiq D, Kirmani A, Salim O, et al. Clinicopathological characteristics of meningiomas: experience from a tertiary care hospital in the Kashmir Valley. Asian J Neurosurg. 2019 Jan-Mar;14(1):41-6. https://doi.org/10.4103/ajns.AJNS_228_16

27. Kuratsu J, Ushio Y. Epidemiological study of primary intracranial tumors in childhood. A population-based survey in Kumamoto Prefecture, Japan. Pediatr Neurosurg. 1996 Nov;25(5):240-6. https:// doi.org/10.1159/000121132

28. Chan RC, Thompson GB. Morbidity, mortality, and quality of life following surgery for intracranial meningiomas. J Neurosurg. 1984 Jan;60(1):52-60. https://doi.org/10.3171/jns.1984.60.1.0052

29. Mirimanoff RO, Dosoretz DE, Linggood RM, Ojemann RG, Martuza $\mathrm{RL}$. Meningioma: analysis of recurrence and progression following neurosurgical resection. J Neurosurg. 1985 Jan;62(1):18-24. https:// doi.org/10.3171/jns.1985.62.1.0018

30. Gennatas ED, Wu A, Braunstein SE, Morin O, Chen WC, Magill ST, et al. Preoperative and postoperative prediction of long-term meningioma outcomes. PLoS One. 2018 Sep;13(9):e0204161. https://doi. org/10.1371/journal.pone.0204161

31. Jääskeläinen J. Seemingly complete removal of histologically benign intracranial meningioma: late recurrence rate and factors predicting recurrence in 657 patients. A multivariate analysis. Surg Neurol. 1986 Nov;26(5):461-9. https://doi.org/10.1016/0090-3019(86)90259-4

32. Hijiya N, Hudson MM, Lensing S, Zacher M, Onciu M, Behm FG, et al. Cumulative incidence of secondary neoplasms as a first event after childhood acute lymphoblastic leukemia. JAMA. 2007 Mar 21;297(11):1207-15. https://doi.org/10.1001/jama.297.11.1207

33. Sadetzki S, Flint-Richter P, Ben-Tal T, Nass D. Radiation-induced meningioma: a descriptive study of 253 cases. J Neurosurg. 2002 Nov;97(5):1078-82. https://doi.org/10.3171/jns.2002.97.5.1078

34. Longstreth Jr WT, Phillips LE, Drangsholt M, Koepsell TD, Custer BS, Gehrels J-A, et al. Dental X-rays and the risk of intracranial meningioma: a population-based case-control study. Cancer. 2004 Mar 1;100(5):1026-34. https://doi.org/10.1002/cncr.20036

35. Ron E, Modan B, Boice Jr JD, Alfandary E, Stovall M, Chetrit A, et al. Tumors of the brain and nervous system after radiotherapy in childhood. N Engl J Med. 1988 Oct 20;319(16):1033-9. https://doi. org/10.1056/NEJM198810203191601

36. Preston DL, Ron E, Yonehara S, Kobuke T, Fujii H, Kishikawa M, et al. Tumors of the nervous system and pituitary gland associated with atomic bomb radiation exposure. J Natl Cancer Inst. 2002 Oct 16;94(20):1555-63. https://doi.org/10.1093/jnci/94.20.1555

37. Al-Mefty O, Topsakal C, Pravdenkova S, Sawyer JR, Harrison MJ. Radiation-induced meningiomas: clinical, pathological, cytokinetic, and cytogenetic characteristics. J Neurosurg. 2004 Jun;100(6):100213. https://doi.org/10.3171/jns.2004.100.6.1002 
38. Al-Mefty O, Kadri PAS, Pravdenkova S, Sawyer JR, Stangeby C, Husain M. Malignant progression in meningiomas: documentation of a series and analysis of cytogenetic findings. J Neurosurg. 2004 Aug;101(2):210-8. https://doi.org/10.3171/jns.2004.101.2.0210
39. Evans DGR, Watson C, King A, Wallace AJ, Baser ME. Multiple meningiomas: differential involvement of the NF2 gene in children and adults. J Med Genet. 2005 Jan;42(1):45-8. https://doi. org/10.1136/jmg.2004.023705 